\title{
Defining and Classifying Learning Outcomes: A Case Study
}

\author{
Maria José Angélico Gonçalves \\ Polytechnic of Porto/ISCAP, \\ Porto, Portugal \\ miose@iscap.ipp.pt \\ Luís Braga \\ Polytechnic of Porto/ISEP, \\ Porto, Portugal \\ lukapt@gmail.com
}

\author{
Pedro Pimenta \\ Minho University, \\ Guimarães, Portugal \\ pedroccpimenta@gmail.com \\ Manuel Pérez Cota \\ Vigo University, \\ Vigo, Spain \\ mpcota@uvigo.es
}

\begin{abstract}
Bologne came to globalize education in higher education, creating a unified architecture that potentiates higher education and enhances the continued interconnection of the spaces of education policy in higher education in the world, in particular in Europe. The aim of this work consists in the presentation of an identification model and skills' classification and learning outcomes, based on the official documents of the course units (syllabus and assessment components) of a course of Higher Education. We are aware that the adoption of this model by different institutions, will contribute to interoperability learning outcomes, thus enhancing the mobility of teachers and students in the EHEA (European Higher Education Area) and third countries.
\end{abstract}

Keywords: Learning Outcomes, Interoperability, Bologne, Syllabus, Topics.

\section{Introduction}

Since implementation of the Bologne process, the curriculum has become a focus of attention of European Universities, within in the context of the European Higher Education Area (EHEA) and the Bologne Process. European Higher Education Institutions, inserted the context of the EHEA and the Bologna process, have organized their curricula so as to conform more to the guidelines patents in the Bologne Declaration. In Portugal, the Decree-Law nrs. 49/2005: Subsection IV $2005,74 / 2006,65 / 2006$ and 107/2008 regulate these guidelines.

The mobility and employability of students in EHEA are goals advocated by Bologne since 1999 .

Material published as part of this publication, either on-line or in print, is copyrighted by the Informing Science Institute. Permission to make digital or paper copy of part or all of these works for personal or classroom use is granted without fee provided that the copies are not made or distributed for profit or commercial advantage AND that copies 1) bear this notice in full and 2) give the full citation on the first page. It is permissible to abstract these works so long as credit is given. To copy in all other cases or to republish or to post on a server or to redistribute to lists requires specific permission and payment of a fee. Contact Publisher@InformingScience.org to request redistribution permission.
The mobility of high quality contributes to the expansion and academic exchange and transfer of knowledge and innovations. Mobility is essential to ensure higher quality education and is also an important pillar for exchange and collaboration with other parts of the world (EHEA, 2012).

Thus, it is necessary to create a coherent, compatible, competitive and attrac- 
tive space for students and teachers, not only Europeans as well as third world countries, where teaching and research can be shared.

The development of tools for comparing curricula is of special interest in the EHEA context because it has the potential to promote the improvement of the syllabus of different educational institutions and allow these to harmonize with the demands of the labour market and international trends in corresponding sectors of the economy, which, in turn, may increase the overall quality of education, and in particular, facilitate the mobility of students. On 23 April 2008, the Presidents of the European Parliament and of the Council of the European Union signed the Recommendation on the European Qualifications Framework for Lifelong Learning (EQF), being formally adopted (Appendix A).

The purpose of this article is to develop, systematize and describe the study that aims to identify and classify the Learning Outcomes (LO) of the Course Units (CU) of a scientific area of a course in Business Sciences, based on competences and LO extracted from official documents, in the areas of Education/Information Management applied to Web and Educational Technology.

Structurally the article is divided into seven sections. After describing the concepts, the problem, the objectives and the investigation questions are defined. Then, the research strategy is presented in order to achieve the objectives and the results obtained. Finally, the conclusions and proposals for future work are presented.

\section{Definition of Concepts}

There are many and diversified definitions that exist in the literature for the word curriculum. In our opinion, perhaps the most consensual is the definition presented by Ribeiro (1996) - curriculum is a "structured plan and sequence of teaching and learning, which includes objectives, contents, strategies, activities and learning evaluation, covers different scopes (macro or micro), relates to contexts (formal or informal) and educational experiences (explicit or implicit) in school."

To define the concept of LO we adopt the terminology used in the European Commission (2008), "increasingly used by Member States", in accordance with CEDEFO (2010). The European Commission (2008) defines LO "as what a learner knows, understands and is able to do" on completion with success of a learning process, described in terms of knowledge, skills and competences, of which:

- Knowledge, also designated as "Knowledge \& Understanding" (UCE Birmingham, 2006), the result of assimilation of information through learning. Knowledge is the body of facts, principles, theories and practices related to an area of work or study.

- Skills, also designated as "Intellectual (thinking) Skills" and "Practical Skills (subjectspecifics)" (UCE Birmingham, 2006), the ability to apply knowledge and use resources acquired to complete tasks and troubleshoot, to describe themselves as cognitive skills (including the use of logical, intuitive and creative thinking) and practical skills (involving manual dexterity and the use of methods, materials, tools and instruments).

- Competences, also designated as "Key/Transferable Skills (generic)" (UCE Birmingham, 2006) and Competences (CEDEFO, 2010), the proven ability to use knowledge, the skills and the personal capabilities, social and/or methodological in professional situations or study contexts and for the purposes of professional and personal development.

That is, the LO can be defined as what the learner knows, understands and is able to do on completion of a learning process, described in terms of knowledge, skills and competence (Knowledge, skills and competence). 


\section{Objectives and Investigation Questions}

The present investigation has as its objective the development of a model of extraction, classification and organization of the LO of a scientific area of a course in business sciences.

To pursue the goal mentioned, we define the following specific objectives:

1. Identify what one learns regarding IST (Information Systems and Technology), in the CU of the scientific area of Information Technology, of the degree in Accounting and Administration of ISCAP/IPP, taking into consideration that the granularity of the contents can vary within the same curriculum. This variability is reinforced if we take into account curricula from various countries with different traditions (Laborde et al., 2008).

2. Understand the level of complexity of the content taught, given specific powers in the field of knowledge (Bloom, 1989) and transferable skills, including skills for living and working in the information society and knowledge (Harel cited in Crespo, L, 2010).

3. Manage the LO, classified by categories, using a Database Management System (DBMS).

To begin the study, we define the following research question:

\section{What are the $\mathrm{LO}$ expected at the conclusion of $\mathrm{CU}$ of a scientific area, of a Higher Education course?}

According to the Recommendation of the European Parliament and of the Council for implementing of the EQF, in 2008, the LO to be undertaken in higher education should result in the acquisition by students of a set of specific and generic training skills. This notion of competence should normally be understood in a broad sense of acquisition of skills, knowledge and qualifications indispensable to the exercise of a given activity or to obtain a particular professional profile. The acquisition of competences takes place in the learning environment to which contributes the various curricular units that make up a course. The competences are divided into two large groups:

- Specific skills, specific to each scientific area, which translate by the acquisition, domain, application and communication of understanding in a specific area of knowledge;

- Generic skills, also called transferable skills, common to many higher education courses and which could have instrumental (cognitive skills, methodologies, techniques and linguistic), interpersonal (individual skills developed in cooperation environments, decision and social interaction) or systemic character (adaptation capacities and leadership, initiative and creativity).

In order to operationalize the previously said issue, necessarily in an open and embracing way, we proposed to explore a set of sub questions which they are formulated in Table 1.

The issues are grouped into three categories according to their main focus be directed to the identification of knowledge $(\mathrm{C} 1)$, to educational objectives $(\mathrm{C} 2)$ or transferable skills $(\mathrm{C} 3)$, particularly in IT.

Table 1 - Investigation Questions

C1 - Focus on Identification of knowledge - Content (What?)

Q1: What knowledge (content) is taught in the CU of the scientific area of Information Technology, in the bachelor course of Accounting and Administration at ISCAP / IPP?

Q2: With which detail do we intend to clarify this knowledge (granularity)? 
$\mathrm{C} 2$ - Focus on the classification of educational goals (With that level of requirement?)

Q3: What goals of instruction in the cognitive domain (Knowledge, Understanding, Application, Analysis, Synthesis and Evaluation) should the students have acquired within the knowledge taught (content) in the scientific area of Information Technology, at the conclusion of the respective CU?

C3 - Focus on the classification of generic skills

Q4: What transferable skills, particularly in IT, (IT skills - 3X: eXploration [eXploration], expression [eXpression] and exchange [Exchange]) should the students have acquired in the scientific area of Information Technology, at the conclusion of the respective CU?

\section{State of the Art}

The way we oriented and designed this study, aiming at the treatment of the problem presented in the previous section, depending on the focus, was inspired in different taxonomies.

\section{C1 - Focus on Identification of knowledge - Content (What?)}

In this category we use standards in the areas of business and computer sciences, giving special importance to the NBES (National Business Education Standards) and ACM (Association for Computing Machinery), respectively.

\section{C2 - Focus on the classification of educational goals (With that level of requirement?)}

In the bibliography there are many taxonomies for the classification of educational skills, however we opted for Bloom's taxonomy and for the classification proposed by the EQE, and making a parallelism between both. Bloom's taxonomy was used because it is a standard (Lima, 2003) and, also, by being the classification referenced in the bibliography as the taxonomy to use for the definition of LO (UCE Birmingham, 2006).

\section{C3- Focus on the classification of generic skills}

For the classification of generic skills, also known as transferable skills or attitudes, we chose to use the list of transferable skills proposed by Oxford University which, according to the bibliography is used as the basis of several studies. With regard to IT skills, the methodology used was strongly inspired by the MACC-3X, proposed by Crespo (2010).

\section{Research Strategy}

The strategy chosen to carry out the investigation followed the logic of a case study. A mode of research that Lessard -Hébert, Goyette \& Boutin (1994) classify as little built, more open and less manipulated.

The first stage consisted of the content analysis of official documents used in the CU of Information Technology scientific area: CU syllabus and evaluation components (tests, examinations, individual and group work), in the course of Accounting and Administration of Porto. This analysis allowed us respond to 1,3 and 4 investigation questions formulated in advance.

To decide the detail with which we wanted to clarify the LO, Question 2, we based ourselves on a previous study that aimed to identify what type of Learning Objects are (re) used by Higher Education teachers in their teaching practices (Angélico, M.J; Cota, M; Pimenta, P., 2011). To proceed to the management of information extracted we implemented a database using a DBMS (Database Management System). 


\section{Methodology of analysis and classification of competences and LO}

The technique chosen to proceed to the analysis and interpretation of documents was content analysis.

According to Krippendorff (1988), content analysis is a research technique used for making valid and replicable inferences from data within their contexts. The analysed data can be viewed based on various perspectives. The organization of the content analysis is part of three chronological segments: the pre-analysis; the material exploration; and the interpretation of results.

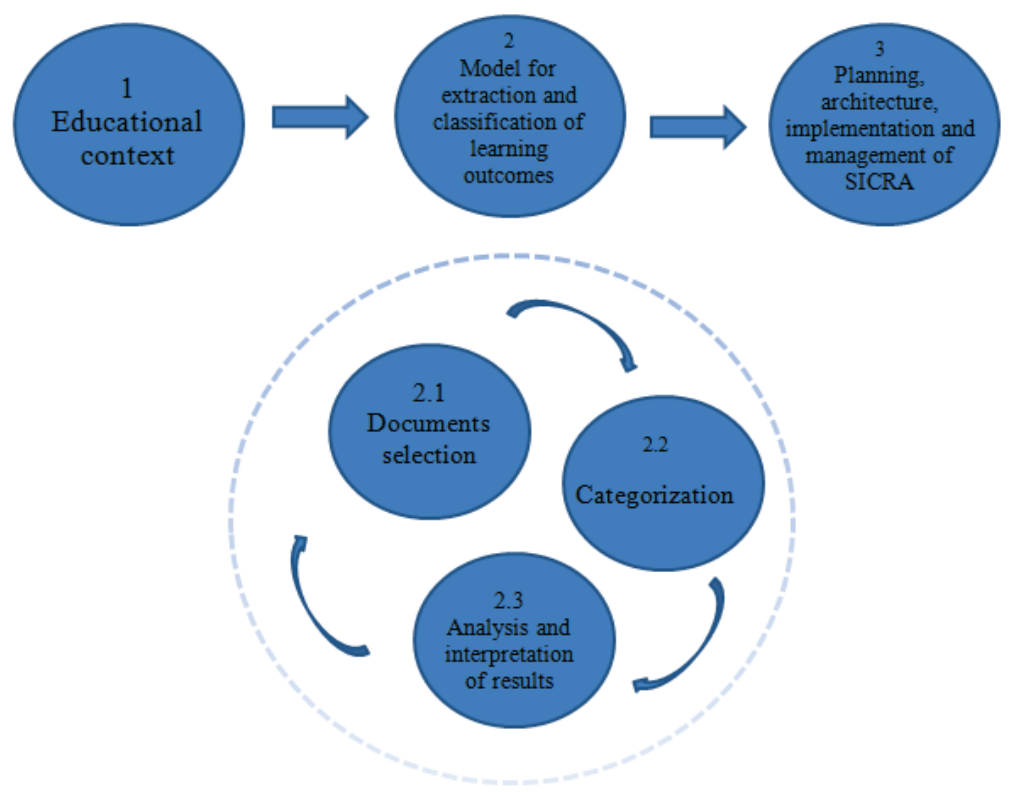

Figure 1 - Analysis and classification model of LO

To proceed to the content analysis, described below, we used the tool WebQDA, proprietary software of analysis of texts, videos, audios and images that runs on a distributed and collaborative environment base on the Internet.

\section{a. The pre-analysis}

The pre-analysis is the organization of the work itself. It is in this stage that the choice of the object under study is made, as well as the formulation of the objectives of the work.

We began our work, observing the syllabus of the CU. After a brief analysis, we found that; by itself, it does not contain the information needed to be able to answer the research questions Q2, Q3 and Q4. In a general way, in the syllabus there are no transferable skills or specific skills that address the entire syllabus. In the syllabus, the topics are not preceded by verbs and therefore it is not possible to identify what kind of competence in the cognitive domain that it is necessary to demonstrate (Definitions, Knowledge, Comprehension, Application, Analysis, Synthesis, and Evaluation).

Therefore, we decided to extend the analysis to all elements of evaluation of the CU. The corpus of this work is consisted of the CU official documents of the scientific area of Information Technology in the course of Accounting and Administration (Technologies and Information Systems and Management Information Systems), including syllabus, tests CA (Continuous Assessment) and examinations, individual and group work and DB (Database) of questions from tests performed on the computer. Table 2 presents the Documental corpus. 
Table 2 - Documental corpus

\begin{tabular}{|c|c|c|}
\hline $\begin{array}{r}\text { Document } \\
\text { Type }\end{array}$ & Documents & $\begin{array}{l}\text { Identification } \\
\text { code }\end{array}$ \\
\hline \multirow{2}{*}{ 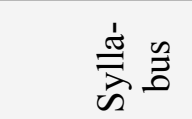 } & Syllabus TIS (Technologies and Information Systems) & P1 \\
\hline & Syllabus MIS (Management Information Systems) & $\mathrm{P} 2$ \\
\hline \multirow{9}{*}{ 畓 } & Theoretical test - TSI (BD Moodle) & BD1 \\
\hline & Practice Test I - IST & $\mathrm{T} 1$ \\
\hline & Practice Test II - IST & $\mathrm{T} 2$ \\
\hline & Exam - IST & E1 \\
\hline & Theoretical test - ISM (BD Moodle) & BD2 \\
\hline & Theoretical test - ISM (Parte 2) & T3 \\
\hline & Practice Test I - ISM & T4 \\
\hline & Practice Test II - ISM & T5 \\
\hline & Exam - ISM & E2 \\
\hline \multirow{4}{*}{ 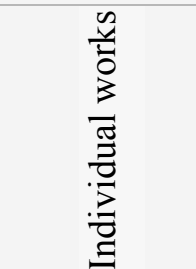 } & Activity $1-$ TSI & A1 \\
\hline & Activity $2-$ TSI & $\mathrm{A} 2$ \\
\hline & Activity 3 - TSI & A3 \\
\hline & Activity from 4 to 9 TSI & A4 \\
\hline \multirow{2}{*}{ 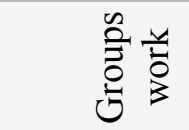 } & Groups work - TSI & TG1 \\
\hline & Group Work - ISM & TG2 \\
\hline
\end{tabular}

This analysis fell on "official documents" (Bodgan \& Bliken 1994) from which we withdrew the information to be analysed. In the study, the documental research "presents itself as a method of collecting and verifying data" (Saint-Georges, 1997). The selection of the documents was conducted in accordance to the objectives defined once the data collection was searched, "as much as possible, gather or make emerge materials" That revealed "systems of sense effectively operating in the subjected" (Hiernaux, 1997).

\section{b. $\quad$ The material exploration}

After selecting the documental corpus of research and having done the "floating reading" (Bardin, 2007; Esteves, 2007) we proceeded with the exploration of the material, by running two fundamental actions (Bardin, 2007), namely:

- The choice of units of register (Context Unit);

- A choice of categories (Classification and aggregation).

In the study, the units of register were made at the semantic level, originating thematic categories (Bardin, 2007; Vala, 2007) - Topics of knowledge - and - Knowledge in the Cognitive Domain.

Then we proceed with the choice of the categories that is a "sort operation of constituent elements of a set, by differentiation, and then by regrouping according to genus (analogy) with previously defined criteria "(Bardin, 2007). 
In this study we used the deductive method of analysis, i.e., we defined a priori that we would use the following categories: "Knowledge Topic", "Skills in the cognitive domain" and "IT Competencies". According to Esteves (2007), the validity of categorization is consistent with the objectives defined, just to be relevant and productive." Therefore, we proceed with construction of a "grid" (Esteves, 2007) of the respective of categories and subcategories, presented in Table 3. We try to harmonize them with the goals of research, also taking into consideration the documentary corpus.

\begin{tabular}{|c|l|}
\hline \multicolumn{2}{|c|}{ Table 3 - Investigation Questions } \\
\hline C1. Knowledge Topic & Subcategories \\
\hline \multirow{2}{|c|}{ Categories } & Sub 1. General Concepts of IT \\
& Sub 2. System and Project Management \\
& Sub 3. Troubleshooting of Accounting \\
& Sub 4. Information Topics \\
\hline C2. Skills in the cognitive domain & Sub1. Knowledge \\
& Sub 2. Comprehension \\
& Sub 3. Application \\
\hline C3. Transferable Skills & Sub 4. Analysis \\
& Sub 5. Synthesis \\
& Sub 6. Evaluation \\
\hline & Sub1. Others \\
& Sub2. IT Skills \\
& Sub 2.1 eXploration \\
& Sub 2.2 eXpression \\
& Sub 2.3 eXchange \\
\hline
\end{tabular}

Table 4 - Investigation Questions

In this part of the study we proceed with the detailed explanation of each category and the respective subcategories in order to clarify the reason of the choices made.

\section{C1 Category - "Knowledge Topic"}

We intend with this category to identify the specific knowledge (knowledge as content assimilated), expected at the conclusion of the $\mathrm{CU}$ in the area of technologies and information systems, generically in business courses and in particular in the course of Accounting and Administration, in the CU of Information Technology at ISCAP. According to the EQF, in 2008, "knowledge must be deepened" which "implies a critical understanding of theories and principles".

To achieve this goal, firstly we identified skills in Information Technologies that students in the courses of Business Sciences (Business) must acquire to live and work in today's society, using the standards proposed by the Business Education Standards Association (NBEA), which are widely used in Secondary and Higher education schools, namely Commonwealth of Pennsylvania, Massachusetts and Wisconsin. 
Then, we analysed of the course curricula in Information Technologies, Information Systems and Computer Sciences. In this area, over time, International Associations ACM, AIS, and IEEE IS have been proposing curricula of courses in technologies and information systems and advising contents for courses that, even though they aren't from the same scientific area, require IT skills. In this analysis we verified that, depending on the context, the concepts/topics cross several knowledge areas.

Pursuing the goal of classifying the topics and subtopics in groups of knowledge, using controlled vocabulary, we adopted the ontology proposed by ACM Computing Classification System, 1998, with the proposed classification updates in 2012, and the classification proposed by the group ITiCSE, in 2008, Computing Ontology of the project.

Then, we proceeded with the intersection of the standards proposed by NBEA with the groups of knowledge obtained as a result of the ratings of the ACM and the ITiCSE group. From this intersection, we concluded that there are groups that are not cited in the NBEA standards, designated in the classification of the ACM, 2012, the "Theory of computation", "Computing methodologies". If we consider the document Computing Curricula, of AIS, IEEE-CS, in 2005, we found that the knowledge units belonging to these groups in the courses in Information Technologies and Information Systems has a weighting average of importance that tends for 0 , being 0 the minimum value and the maximum value 5 .

Finally, we crossed the syllabus topics of the CU with the results obtained previously. From this crossover resulted table 7 (Appendix B). In the observation of this table we verify that the curricular units teaching contents classified into several groups, in the area of Computer Sciences, and that the same covers large part of the contents advised by NBES (11 topics in 18). To be noted, further that, at ISCAP, some of topics not referenced in the syllabus of scientific area of Information Technology ( 7 in 18 topics) form part of the syllabus of other scientific areas, notably in the scientific area of Management and Accounting. This fact is not shown here because it is outside of the scope of our study.

Taking into consideration the analysis effected previously and the aim of the study and the absence of uniformity in the designation and classification of topics by groups of knowledge, we decided to group the contents into the following subcategories, in the category Knowledge Topic: "Sub1.General Concepts of IT", "Sub 2.Systems and Project Management", "Sub 3. Troubleshooting of Accounting" and "Sub 4. Topics Information". The Sub 1. category groups several topics of the classifications proposed by NBES, ACM e ITiCSE, the Sub 2. filters out the topic "Project Management" of the classification of the group ITiCSE, the Sub 3. is new and the Sub 4. filters out the topic "Data Management System" of ACM classification.

\section{C2 Category -Skills in the Cognitive Domain Area}

To identify the type of skills in the domain of knowledge expected upon conclusion of the CU in the subtopic topics of the CU, as previously mentioned, we use Bloom's taxonomy. This taxonomy is structured into six levels of increasing complexity: knowledge, comprehension, application, analysis, synthesis and evaluation.

\section{C3 Category - Transferable Skills}

With the category C3 we intend to identify the transferable skills, which may take instrumental (cognitive capacities, methodological, technical and linguistic), interpersonal (individual skills developed in environments of cooperation, decision making and social interaction) or systemic character (adaptation capacities and leadership, initiative and creativity), expected at the conclusion of the CU of scientific area of Informatics, notably in IT. 
In this context, specifically at the competence of Information Technologies, we used the classification proposed by Harel Idit (cited in Crespo, L., 2010) defines eXploration, eXpression and eXchange as essential skills for living and working in the information and knowledge society.

\section{c. $\quad$ The interpretation of results}

The next moment, is the stage of the processing of the results, of inference, of interpretation of the search for answers to the questions following the guiding of the investigation (Esteves, 2007). It is presented in the following section.

\section{Presentation of Results}

\section{The Data Description}

\section{C1 Category - "Knowledge Topic"}

To proceed with the listing of the contents taught in the CU, we start by analysing the documents ${ }^{1}$ [P1] and [P2], sections objectives/ syllabus and competence. Then, we classify them according to the subcategories [Sub1], [Sub2], [Sub3], [Sub4] belonging to the category C1 ("Knowledge Topic"), described in the preceding section. In this analysis, we verify that the information made available in the documents previously mentioned did not permit us to understand with clarity the specific knowledge required by the students (contents) because they had low granularity (very generic topics). We decided therefore also to analyse the evaluation components of the CU, including databases [BD1] and [BD2], which contain the questions from which result the theoretical tests, performed in LMS Moodle, an example of CA tests [T1], [T2], [T3] [T4] and [T5], an example of final exams [E1] and [E2], individual assignments [A1] [A2], [A3] and [A4] and the Group work [TG1] and [TG2]. According to the QAA (Quality Assurance Agency for Higher Education), in order to make an assessment of the courses, it is necessary for the specific outcomes of learning to be included in the syllabus of the CU, courses or modules. Otherwise, the LO will be obtained through the collection of evidences in the entire range of assessment activities (QAA, 2007).

\section{C2 Category -Skills in the Cognitive Domain Area}

To identify the specific skills in the cognitive domain expected upon completion of the CU we use the documents [P1] and [P2], sections: objectives/skills and syllabus. In this analysis we found that the information made available in the documents [P1] and [P2], in syllabus section, does not allow us to understand the maturity level of knowledge required to students within the content taught (Bloom, 1971), since the topics are not preceded by any verb. We decided therefore also to analyse the documents that constitute the components of evaluation of the CU ([T1], [T2], [T3], [T4], [T5], [E1], [E2], [A1], [A2], [A3], [A4], [TG1] and [TG2]). The 6 subcategories of category $\mathrm{C} 2$ correspond to six levels of Bloom. The content classification, on a certain level, depends on the verb that normally precedes the noun (topic/content).

\section{C3 Category - Transferable Skills}

To identify the transferable skills expected upon the completion of the CU, namely in IT, we use the documents [P1] and [P2], sections teaching methodologies/ learning and assessment methodologies, and the documents [A1] [A2] [A3], [A4], [TG1] and [TG2] that correspond to individual and group activities to be performed by students. The selection of these documents, specifically the section teaching methodologies/ learning was due to the fact that we wanted to know if the teachers and students adopted the pedagogical strategies that use IT. According to Laurillard

\footnotetext{
${ }^{1}$ The documents are referenced by codes. The document descriptions can be seen in Table 2 .
} 
(1993) the use of these strategies can promote active learning more student-centred, valuing their personal experiences and their participation.

\section{Interpretation of Results}

To answer question Q1 we classify the units of registration in the Knowledge Topic category

In relation to question Q2 we opted to introduce 2 or 3 levels of detail in the topics taught (one or two layers below the "Knowledge Topic"), due to the fact that a syllabus with the detailed topics is more explicit.

Then we used the classifications proposed by the ACM, in 2012 and by the ITiCSE, in order to identify the topics and subtopics. We opted, whenever possible, for the classification of ACM as it is implemented in OWL language. When a topic or subtopic is not included in the classification of the ACM, we used the term proposed by group ITiCSE, 2008. If it was not listed in any of the classifications we defined it.

From this analysis we obtained the list of topics (Q1) and subtopics (Q2) taught in the CU, in the scientific area of Information Technology at ISCAP, by Knowledge Topic. Table 4 shows General Concepts of IT Topic.

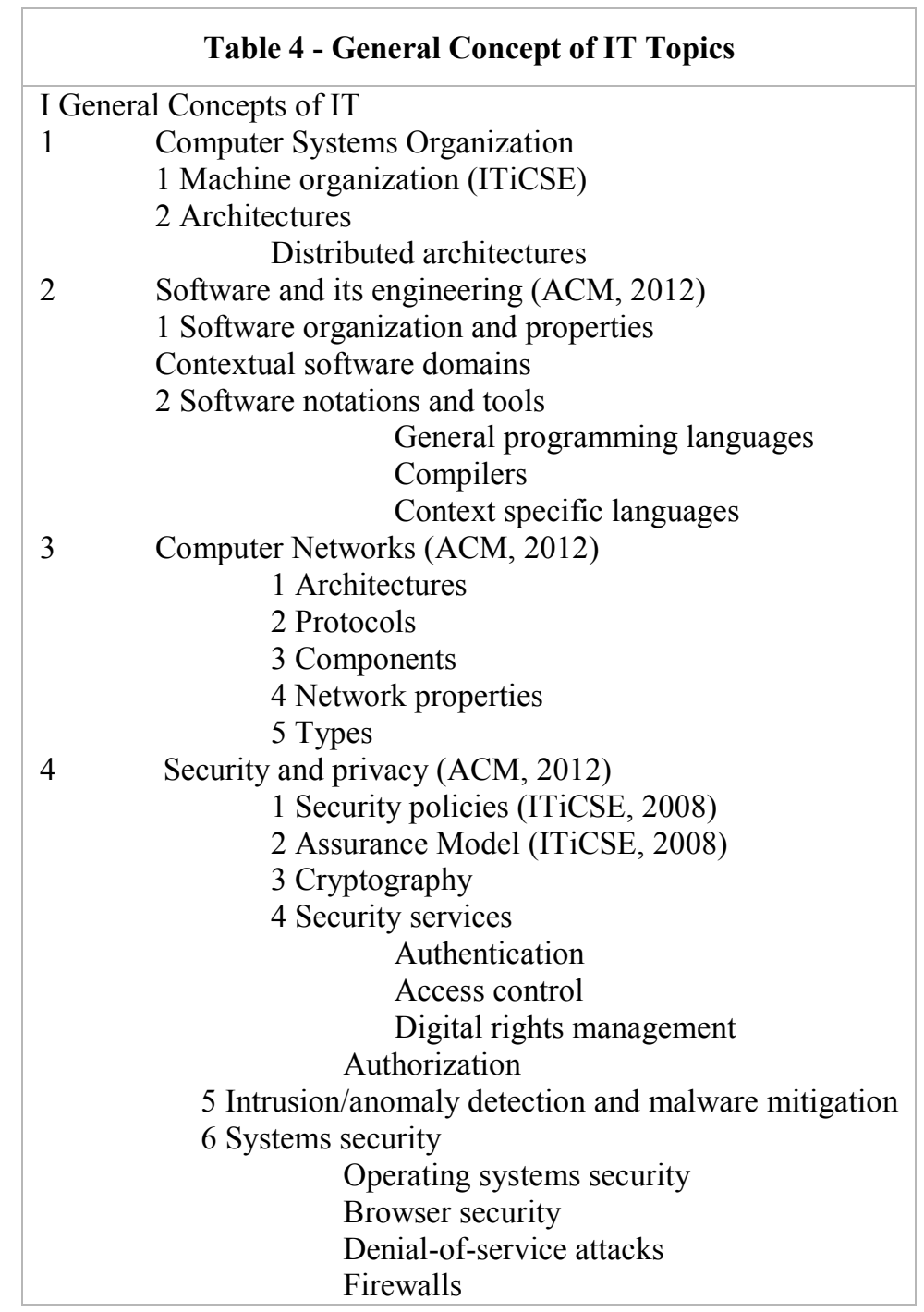




\begin{tabular}{|c|}
\hline Vulnerability management \\
File system security \\
7 Network security \\
Web protocol security \\
Mobile and wireless security \\
Denial-of-service attacks \\
Firewalls \\
$5 \quad$ Applied computing (ACM, 2012) \\
1 Electronic commerce \\
2 Enterprise computing \\
3 Education \\
4 Computers in other domains
\end{tabular}

In relation to the question Q3, we intersected of the Knowledge Topic categories ("C1. Knowledge Topic") and C2 (Skills in the Cognitive Domain). The following figure shows an extract of the analysis performed.

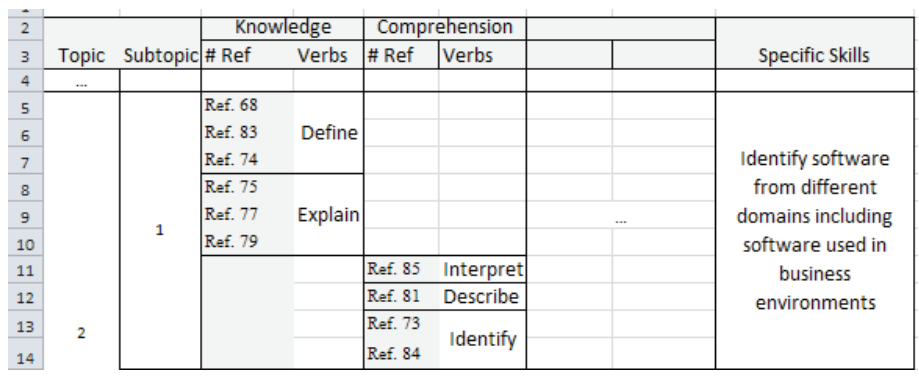

Figure 2 - Specific skills extract

According to the analysis carried out, and taking into consideration that students at the end of the study cycle, should have acquired specific skills (attitudes) of level 6 (EQF), the same applies, after completing the teaching of the topic General Concept of IT in the domain of cognitive knowledge, where students should have acquired the specific skills listed in Table 5.

\section{Table 5 - Specific skills of General Concepts of IT extract}

1. Define computer system organization

2. Identify software from different domains including software used in business environment.

3. ...

4. Conceive one proposed acquisition of a computer system with details of the physical characteristics and logic, substantiating the choice.

To answer question Q4 we analysed the registration units classified according to the category C3 "Transferable Skills".

According to the analysis, and taking into consideration that students at the end of the study cycle, should have acquired generic skills (attitudes) of level 6, the same applies, after concluding the Curricular Unit of IST, students should have acquired the transversal skills listed in Table 6. Having answered questions Q1, Q2, Q3 and Q4 we gathered the conditions warranting to proceed with the presentation of the $\mathrm{LO}$ of the $\mathrm{CU}$ of scientific areas of the course. 


\section{Table 6 - Transferable skills of CU TIS}

1. Self-management

2. Group work

3. Study skills

4. Communication skills

5. IT skills: eXploration, eXpression and eXchange.

Figure 3 shows the parallelism between Bloom's taxonomy and the EQF.

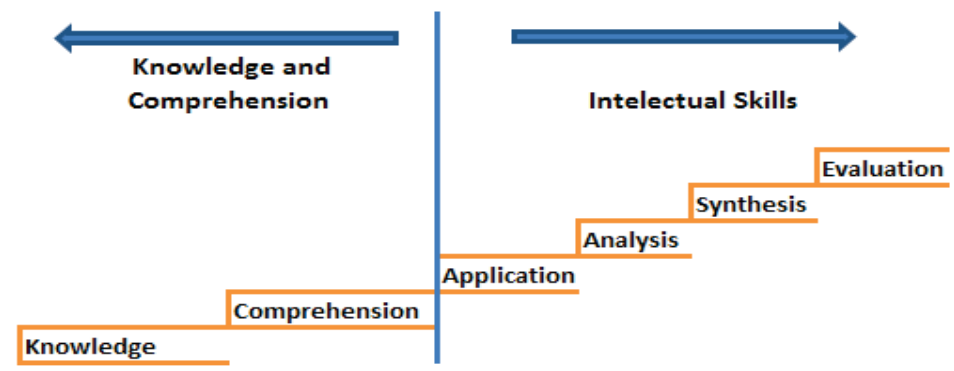

Figure 3 - Bloom vs EQF

The junction of the information obtained in responses Q1, Q2 and Q4, using the classification presented in the previous figure enables us to obtain the LO of the CU of scientific areas of the course, according to the EQF.

\section{Data base implementation}

We presents the conceptual model of Database "SICRA" developed with the goal to store, manipulate and search for information from our study case

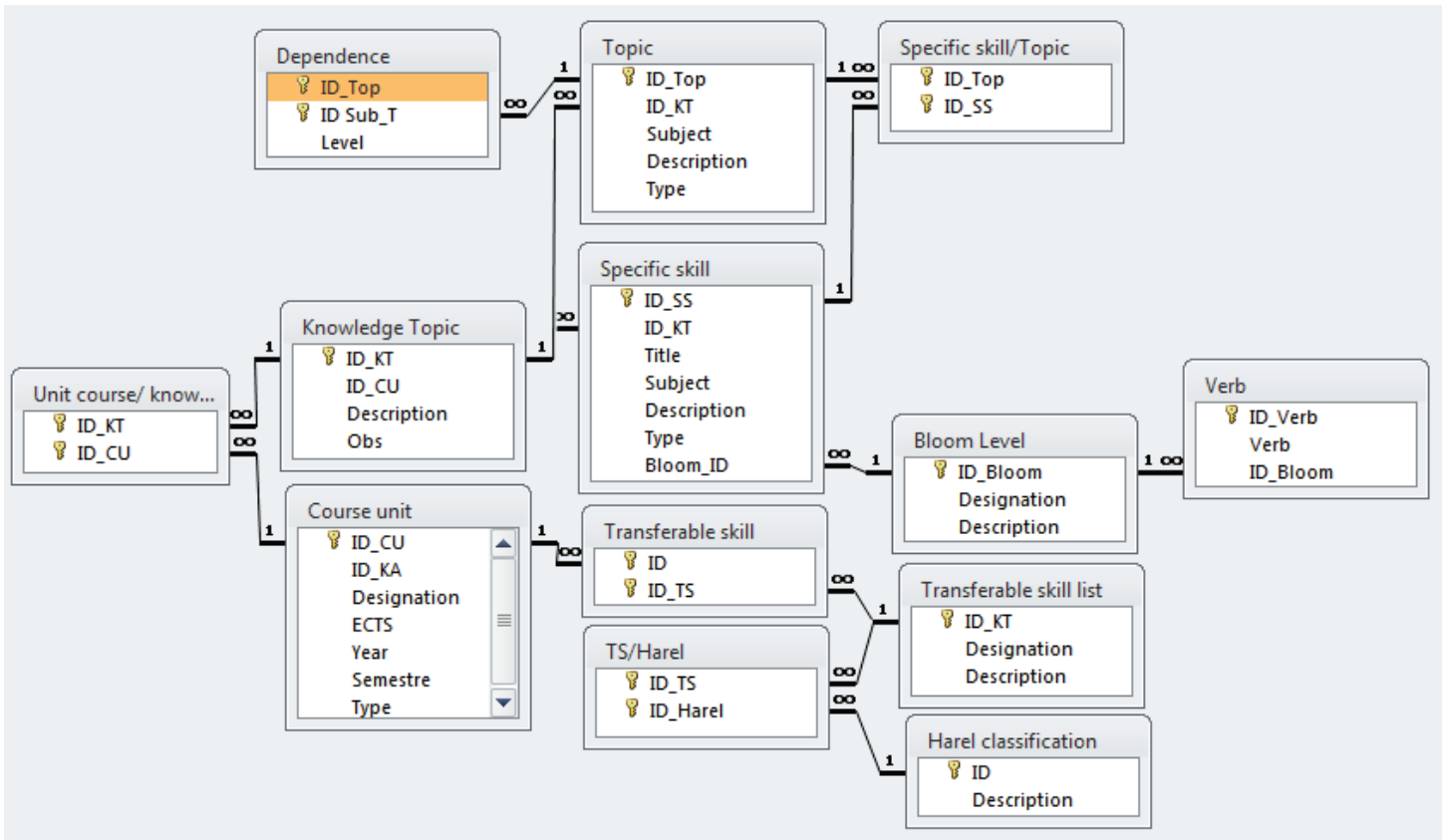

Figure 4 - DB Conceptual model

Then, database queries will be presented. 


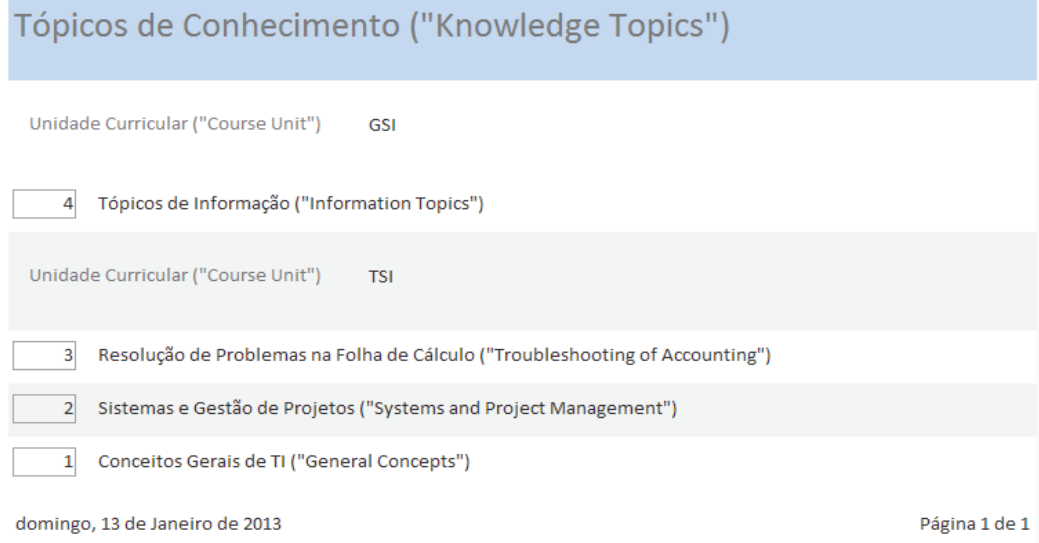

Figure 5- Knowledge Topics by CU

\begin{tabular}{|c|c|}
\hline & \multicolumn{1}{c|}{ TÓPICOS ("TOPICS") } \\
\hline UC ("CU"): TSI & \\
Descrição ("Description") & Conceitos Gerais de TI ("General Concepts") \\
Nivel ("Level") & Assunto ("Subject") \\
1 & Software and its engineering \\
1 & Computer Systems Organization \\
2 & Software notations and tools \\
2 & Software organization and properties \\
2 & Architectures \\
2 & Machine organization \\
3 & Context specific languages \\
3 & Compilers \\
3 & General programming languages \\
3 & Distributed architectures \\
\hline
\end{tabular}

Figure 6 - Topics by knowledge topic

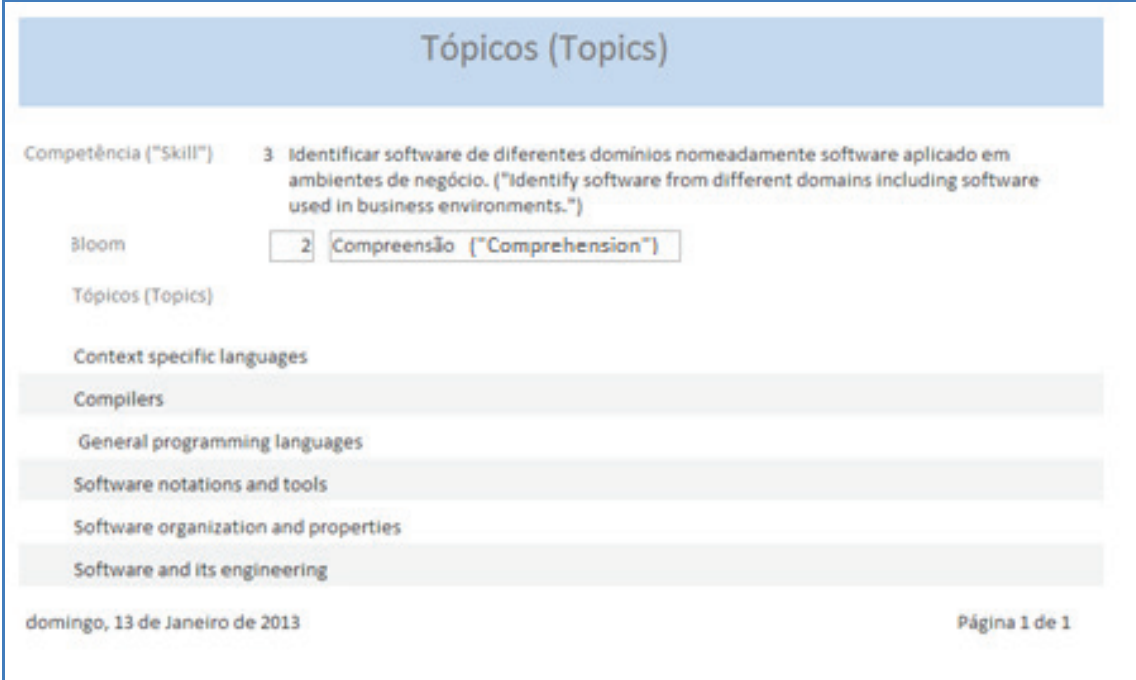

Figure 7 - Topics by specific competence 


\section{Conclusions and Future Work}

In the last two decades, we have witnessed a set of transformations in higher education, in order to construct a European Area of Higher Education, focalized on harmonization and comparability of knowledge and procedures and in the excellence of results, capable of attracting new students and teachers.

One of the objectives of this process, since its inception, is to encourage mobility of students and teachers between the higher education establishments, ensured through the European Credits Transfer System (ECTS), based on the principle of mutual recognition of the value of the formation and of skills acquired (Decree-Law n. ${ }^{\circ}$ 74/2006). The mobility of students within Europe highlights the need for information exchange between institutions of higher education.

In this article, we have proposed a methodology of classification and extraction of the LO, by using a case study with a view to the promotion of mobility in the EHEA.

With the information resulting from the application of the methodology at the end of the chapter, we implemented a BD, by using a relational DBMS.

The scientific advances achieved in areas such as the Semantic Web ends potential contributions to the automatization of the interoperability between institutions in higher education, namely in LO interoperability. We intend to develop and available this ontology.

\section{References}

ACM. (2012). Computing classification system, 2012 Revision. Association for Computing Machinery. Retrieved from http://www.acm.org/about/class/2012

Bardin, L. (2007) Análise de conteúdo. Lisboa: Edições 70.

Bloom, B. S., \& Krathwol, D. R., (1989). Taxonomy of educational objectives book 1: Cognitive domain. New York: Longman Publishing.

Bogdan, R. \& Biklen, S. (1994). Investigação Qualitativa em Educação - Uma Introdução à Teoria e aos Métodos. Porto: Porto Editora.

Cassel, L. N., Davies, G., LeBlanc, R., Snyder, L., \& Topi, H. (2008). Using a computing ontology as a foundation for curriculum development. Proceedings of the Sixth International Workshop on Ontologies \& Semantic Web for E-Learning (pp. 21-29). Montreal, Canada.

CEDEFOP. (2010) Learning outcomes approaches in VET curricula. A comparative analysis of nine European countries. Publications Office of the European Union, 2010. Retrieved from http://www.cedefop.europa.eu/EN/Files/5506_en.pdf\#

Crespo, L. V., \& Pérez Cota, M. (2010). Integración real de la informática en el sistema educativo no universitario de Galicia. Implicaciones, problemática actual y aportaciones para la contextualización y desarrollo de la Informática Educativa. Tesis correspondiente al Programa de Doctorado em Informática Avanzada Para obtener el grado de Doctor.

EHEA. (2012). Mobility strategy 2020 for the European Higher Education Area. Ministerial Conference, Bucharest.

Esteves, M. (2007). Análise de conteúdo. In J. Lima \& J. A. Pacheco (orgs.). Fazer investigação. Contributos para a elaboração de dissertações e teses. Porto: Porto Editora.

European Commission. (2008). Recommendation of the European Parliament and of the Council of 23 April 2008 on the establishment of the European Qualifications Framework for lifelong learning. OJ C $111,6.5 .2008$

Gonçalves, M. J. A., Pérez Cota. P., \& Pimenta P. (2011). Que Learning Objects (LOs) utilizam as Instituições de Ensino Superior? Information Systems and Technologies (CISTI), 2011 6th Iberian 
Conference on Issue, 15-18, June 2011, pp.1-5. Retrieved from

http://ieeexplore.ieee.org/xpl/mostRecentIssue.jsp?punumber=5962051

Hiernaux, J-P. (1997). Análise estrutural de conteúdos e modelos culturais: aplicação a materiais volumosos. In L. Albarello, F. Digneffe, J. P. Hiernaux, C. Maroy, D. Ruquoy \& P. Saint-Georges. Práticas e Métodos de Investigação em Ciências Sociais. Lisboa: Gradiva

Krippendorf, K. (1980). Content analysis. An introduction to its methodology. London: Sage.

Laborde C., Dietrich, M., Creus-Mir, A., Egido, S., Homik, M., \& Libbrecht, P. (2008). I2G Intergeo. Intergeo Consortium, 2008. Retrieved from http://i2geo.net/files/deliverables/D2.5-CurriculaCategorisation.pdf

Laurillard, D. (1993). Rethinking university teaching: A framework for the effective use of educational technology. London: Routledge.

Lessard-Hébert, M., Goyette, G., Boutin, G. (1994). Investigação Qualitativa: Fundamentos e Práticas, Lisboa: Instituto Piaget.

Lima, J. R. \& Capitão, Z. (2003). E-Learning e e-conteúdos: Aplicações das teorias tradicionais e modernas de ensino e aprendizagem à organização e estruturação de Recursos. Centro Atlântico. ISBN 9728426720.

QAA. (2007). Accounting 2007. The Quality Assurance Agency for Higher Education 2007, ISBN 9781 84482672 1, available at www.qaa.ac.uk

Ribeiro, A. C. (1996). Desenvolvimento curricular (6th ed.). Lisboa: Texto Editora.

Saint-Georges, P. (1997). Pesquisa e crítica das fontes de documentação nos domínios económico, social e político. In L. Albarello, F. Digneffe, J. P. Hiernaux, C. Maroy, D. Ruquoy e P. Saint-Georges. Práticas e Métodos de Investigação em Ciências Sociais. Lisboa: Gradiva.

UCE Birmingham. (2006). Guide to learning outcomes. Retrieved from http://www.ssdd.bcu.ac.uk/outcomes/\#2.\%20What\%20are\%20Learning\%20Outcomes

Vala, J. (1986). A análise de conteúdo. In A. S. Silva e J. M. Pinto (orgs.). Metodologia das ciências sociais. Lisboa: Afrontamento.

\section{Biographies}

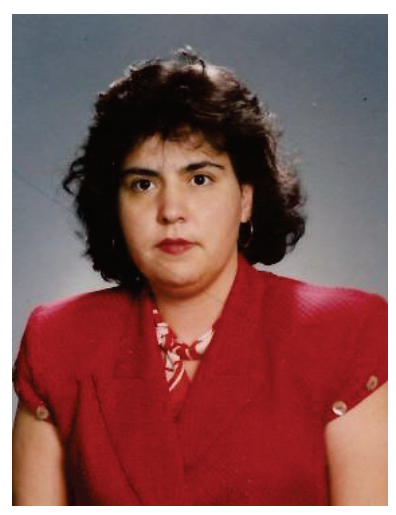

Maria José Angelico Gonçalves is an Adjunct Professor of Scientific area of Computer Science in School of Accountancy and Administration of Porto of Polytechnic Institute of Porto. She is a Ph.D student at the University of Vigo. Her research interests focus Education/Learning and Educational Technology. She is author of some publications in these areas. 

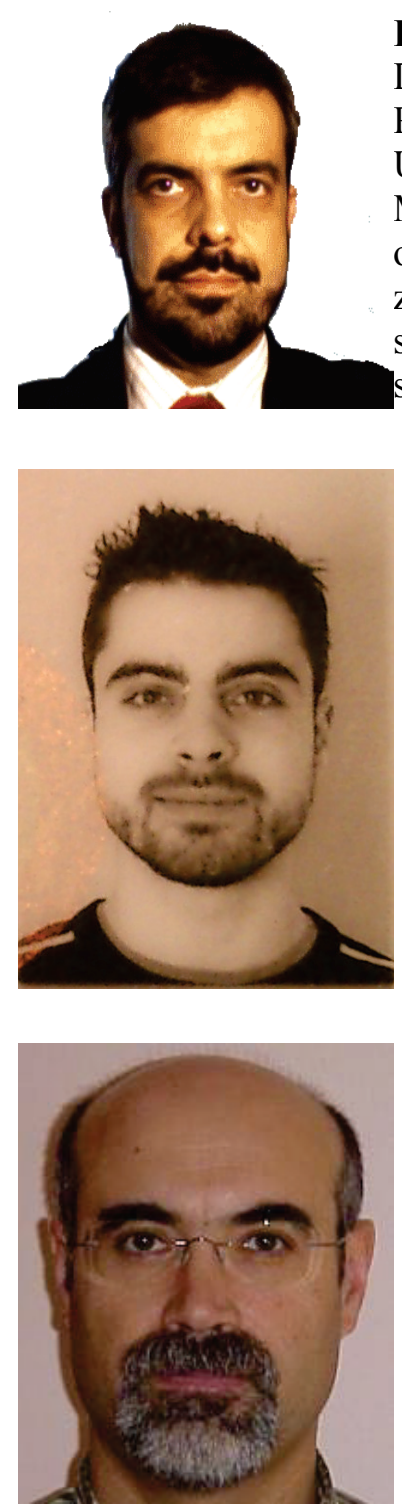

Pedro Correia Cravo Pimenta is Professor Auxiliar Convidado in the Departmento de Sistemas de Informação at Universidade do Minho, Portugal. He received is $\mathrm{PhD}$ on Control of Chemical Processes by the Universidade do Porto (1997), and is working in the Universidade do Minho since then. His research activity focused on technology adoption on learning institutions context, including both pedagogical and organizational support aspects. Has been involved in a tenth of Europeansupported projects and member of organizing and program committes of several national and international conferences, member of IEEEE and secretary of IEEE-RITA.

Luís Braga is a Researcher in the Knowledge Engineering and Decision Support Research Center (GECAD) and is completing a master's degree in computer engineering, in the area of knowledge technologies and decision, at Institute of Engineering - Polytechnic of Porto. His research interests include Ontology Engineering, particularly the temporal and spatial representation and reasoning.

Manuel Pérez Cota is a Professor in Department of Informatics, Area of Computer Systems and Software, School of Technical Industrial Engineering University of Vigo. He receivd a PhD. course on: Informática Avanzada (Advanced Informatics, computer science) and $\mathrm{PhD}$ course on: Multimedia/Hipermedia \& HCI to "Universidad de las Palmas de Gran Canaria".His research interest include Computer Aided Teaching and Learning with Hypermedia/Multimedia Systems and based on Web, Software Engineering, Object Oriented Systems and Security. (Java, C++) and Human-Computer Interation (HCI) and Graphical Systems. 


\section{Appendix A}

The European Qualifications Framework (EQF)

\begin{tabular}{|c|c|c|c|}
\hline Level & Knowledge & Skills & Competence \\
\hline Level 1 & Basic general knowledge & $\begin{array}{l}\text { basic skills required to carry out simple } \\
\text { tasks }\end{array}$ & $\begin{array}{l}\text { work or study under direct supervision in a } \\
\text { structured context }\end{array}$ \\
\hline Level 2 & $\begin{array}{l}\text { Basic factual knowledge of a } \\
\text { field of work or study }\end{array}$ & \begin{tabular}{|l|} 
basic cognitive and practical skills re- \\
quired to use relevant information in order \\
to carry out tasks and to solve routine \\
problems using simple rules and tools
\end{tabular} & $\begin{array}{l}\text { work or study under supervision with some } \\
\text { autonomy }\end{array}$ \\
\hline Level 3 & $\begin{array}{l}\text { Knowledge of facts, principles, } \\
\text { processes and general concepts, } \\
\text { in a field of work or study }\end{array}$ & \begin{tabular}{|l|} 
a range of cognitive and practical skills \\
required to accomplish tasks and solve \\
problems by selecting and applying basic \\
methods, tools, materials and information
\end{tabular} & $\begin{array}{l}\text { take responsibility for completion of tasks in } \\
\text { work or study; adapt own behaviour to cir- } \\
\text { cumstances in solving problems }\end{array}$ \\
\hline Level 4 & $\begin{array}{l}\text { Factual and theoretical } \\
\text { knowledge in broad contexts } \\
\text { within a field of work or study }\end{array}$ & $\begin{array}{l}\text { a range of cognitive and practical skills } \\
\text { required to generate solutions to specific } \\
\text { problems in a field of work or study }\end{array}$ & $\begin{array}{l}\text { exercise self-management within the guide- } \\
\text { lines of work or study contexts that are usu- } \\
\text { ally predictable, but are subject to change; } \\
\text { supervise the routine work of others, taking } \\
\text { some responsibility for the evaluation and } \\
\text { improvement of work or study activities } \\
\end{array}$ \\
\hline Level $5^{[1]}$ & \begin{tabular}{|l|} 
Comprehensive, specialised, \\
factual and theoretical knowledge \\
within a field of work or study \\
and an awareness of the bounda- \\
ries of that knowledge
\end{tabular} & $\begin{array}{l}\text { a comprehensive range of cognitive and } \\
\text { practical skills required to develop crea- } \\
\text { tive solutions to abstract problems }\end{array}$ & $\begin{array}{l}\text { exercise management and supervision in } \\
\text { contexts of work or study activities where } \\
\text { there is unpredictable change; review and } \\
\text { develop performance of self and others }\end{array}$ \\
\hline Level $6^{[2]}$ & $\begin{array}{l}\text { Advanced knowledge of a field of } \\
\text { work or study, involving a critical } \\
\text { understanding of theories and } \\
\text { principles }\end{array}$ & $\begin{array}{l}\text { advanced skills, demonstrating mastery } \\
\text { and innovation, required to solve complex } \\
\text { and unpredictable problems in a special- } \\
\text { ised field of work or study }\end{array}$ & $\begin{array}{l}\text { manage complex technical or professional } \\
\text { activities or projects, taking responsibility } \\
\text { for decision-making in unpredictable work } \\
\text { or study contexts; take responsibility for } \\
\text { managing professional development of indi- } \\
\text { viduals and groups }\end{array}$ \\
\hline Level $7^{[3]}$ & $\begin{array}{l}\text { Highly specialised knowledge, } \\
\text { some of which is at the forefront } \\
\text { of knowledge in a field of work } \\
\text { or study, as the basis for original } \\
\text { thinking and/or research } \\
\text { Critical awareness of knowledge } \\
\text { issues in a field and at the inter- } \\
\text { face between different fields }\end{array}$ & $\begin{array}{l}\text { specialised problem-solving skills re- } \\
\text { quired in research and/or innovation in } \\
\text { order to develop new knowledge and } \\
\text { procedures and to integrate knowledge } \\
\text { from different fields }\end{array}$ & $\begin{array}{l}\text { manage and transform work or study con- } \\
\text { texts that are complex, unpredictable and } \\
\text { require new strategic approaches; take re- } \\
\text { sponsibility for contributing to professional } \\
\text { knowledge and practice and/or for reviewing } \\
\text { the strategic performance of teams }\end{array}$ \\
\hline Level $8^{[4]}$ & $\begin{array}{l}\text { Knowledge at the most advanced } \\
\text { frontier of a field of work or } \\
\text { study and at the interface between } \\
\text { fields }\end{array}$ & \begin{tabular}{|l|} 
the most advanced and specialised skills \\
and techniques, including synthesis and \\
evaluation, required to solve critical prob- \\
lems in research and/or innovation and to \\
extend and redefine existing knowledge \\
or professional practice
\end{tabular} & $\begin{array}{l}\text { demonstrate substantial authority, innova- } \\
\text { tion, autonomy, scholarly and professional } \\
\text { integrity and sustained commitment to the } \\
\text { development of new ideas or processes at the } \\
\text { forefront of work or study contexts including } \\
\text { research }\end{array}$ \\
\hline
\end{tabular}

1. The descriptor for the higher education short cycle (within or linked to the first cycle), developed by the Joint Quality Initiative as part of the Bologna process, corresponds to the learning outcomes for EQF level 5.

2. The descriptor for the first cycle in the Framework for Qualifications of the European Higher Education Area agreed by the ministers responsible for higher education at their meeting in Bergen in May 2005 in the framework of the Bologna process corresponds to the learning outcomes for EQF level 6.

3. The descriptor for the second cycle in the Framework for Qualifications of the European Higher Education Area agreed by the ministers responsible for higher education at their meeting in Bergen in May 2005 in the framework of the Bologna process corresponds to the learning outcomes for EQF level 7.

4. The descriptor for the third cycle in the Framework for Qualifications of the European Higher Education Area agreed by the ministers responsible for higher education at their meeting in Bergen in May 2005 in the framework of the Bologna process corresponds to the learning outcomes for EQF level 8. 


\section{Appendix B. Curriculum Matrix (cross-reference)}

\begin{tabular}{|c|c|c|c|c|}
\hline \multicolumn{2}{|c|}{$\begin{array}{l}\text { Accounting and Administration of } \\
\text { ISCAP/IPP }\end{array}$} & \multirow{2}{*}{$\begin{array}{l}\text { NBES } \\
\text { Topics }\end{array}$} & \multirow{2}{*}{$\begin{array}{c}\begin{array}{c}\text { Computing Classification } \\
\text { System (ACM, 2012) }\end{array} \\
\text { Top Level Concepts }\end{array}$} & \multirow{2}{*}{$\begin{array}{c}\begin{array}{c}\text { Computing Ontology } \\
\text { (Work in progress) }\end{array} \\
\text { Top Level Concepts }\end{array}$} \\
\hline $\begin{array}{l}\text { Unit } \\
\text { courses }\end{array}$ & Area: Computer Science & & & \\
\hline \multirow{5}{*}{$\begin{array}{l}\text { Technolo- } \\
\text { gies and } \\
\text { Infor- } \\
\text { mation } \\
\text { Systems } \\
\text { (TSI) } 48 \\
\text { core } \\
\text { hours }\end{array}$} & $\begin{array}{l}\text { General concepts of IT } \\
\qquad \text { (12 hours): } \\
\text { Components of a com- } \\
\text { puter system }\end{array}$ & $\begin{array}{l}\text { Information Technology: } \\
\text { II. Hardware } \\
\text { IV. Input Technologies } \\
\text { III. Operating Systems and } \\
\text { Utilities } \\
\text { XI. Programming and Ap- } \\
\text { plication Development } \\
\text { XII. Telecommunications } \\
\text { and Networking Infrastruc- } \\
\text { tures }\end{array}$ & $\begin{array}{l}\text { Hardware } \\
\text { Networks } \\
\text { Computer systems or- } \\
\text { ganization } \\
\text { Software and its engi- } \\
\text { neering }\end{array}$ & $\begin{array}{l}\text { Computer Hardware } \\
\text { Organization } \\
\text { Computer and Net- } \\
\text { work Systems } \\
\begin{array}{c}\text { Programming Fun- } \\
\quad \text { damentals }\end{array}\end{array}$ \\
\hline & Security of the IS/ IT & $\begin{array}{l}\text { Information Technology: } \\
\text { XIV. Security, Privacy, and } \\
\text { Risk Management }\end{array}$ & Security and privacy & Security \\
\hline & $\begin{array}{l}\text { Areas of application of } \\
\text { ICT }\end{array}$ & I. Impact on Society & Applied computing & \\
\hline & $\begin{array}{l}\text { Introduction to project } \\
\text { management tools (12 } \\
\text { hours): } \\
\text { Areas of application of } \\
\text { project management } \\
\text { Introduction to } \\
\text { MS_Project }\end{array}$ & & $\begin{array}{c}\text { Social and professional } \\
\text { topics }\end{array}$ & $\begin{array}{l}\text { System and Project } \\
\text { Management }\end{array}$ \\
\hline & $\begin{array}{l}\text { Troubleshooting Ac- } \\
\text { counting (24 hours) } \\
\text { Data analysis through } \\
\text { management simulation } \\
\text { Data analysis through } \\
\text { statistical, mathematical } \\
\text { and financial functions }\end{array}$ & $\begin{array}{l}\text { Information Technology: } \\
\text { V. Productivity Software }\end{array}$ & & \\
\hline \multirow[b]{2}{*}{$\begin{array}{l}\text { Manage- } \\
\text { ment } \\
\text { Infor- } \\
\text { mation } \\
\text { Systems } \\
\text { (MIS) } 48 \\
\text { core } \\
\text { hours }\end{array}$} & $\begin{array}{c}\text { Database Systems (48 } \\
\text { hours): } \\
\end{array}$ & Information Technology: & \multirow[b]{2}{*}{ Information systems } & \multirow[b]{2}{*}{ Information Topics } \\
\hline & $\begin{array}{l}\text { Database Systems } \\
\text { Data Modelling } \\
\text { Study of a Database } \\
\text { Management System }\end{array}$ & $\begin{array}{l}\text { VIII. Information Retrieval } \\
\text { and Synthesis } \\
\text { IX. Database Management } \\
\text { Systems } \\
\text { X. Systems Analysis and } \\
\text { Design }\end{array}$ & & \\
\hline
\end{tabular}

